\title{
Measurement of hydroxychloroquine in blood from SLE patients using LC- HRMS-evaluation of whole blood, plasma, and serum as sample matrices
}

Henrik Carlsson ${ }^{1 \dagger}$, Karin Hjorton ${ }^{2+}$, Sandy Abujrais ${ }^{1}$, Lars Rönnblom ${ }^{2}$, Torbjörn Åkerfeldt ${ }^{1}$ and Kim Kultima ${ }^{1 *}$ (D)

\begin{abstract}
Background: Hydroxychloroquine (HCQ) is the standard of care in the treatment of systemic lupus erythematosus (SLE), rheumatoid arthritis (RA), and other inflammatory rheumatic diseases and potentially for the treatment in COVID-19 patients. Determination of HCQ for therapeutic drug monitoring (TDM) can be performed in whole blood (WB), serum, and plasma. Direct comparisons of WB, serum, and plasma levels of HCQ in patients with SLE have not previously been reported. We describe a method for the determination of HCQ in human blood using liquid chromatography-highresolution mass spectrometry (LC-HRMS) and compare the suitability of the three sample matrices.
\end{abstract}

Methods: A method for the determination of HCQ in human blood using LC-HRMS was developed, validated, and applied for the determination of HCQ levels in WB, serum, and plasma from 26 SLE patients. The reproducibility of the method, in the three matrices, was evaluated using quality control samples and repeated preparations and measurements of patient samples. The performance of the developed method for HCQ measurement in serum was further evaluated by comparison with two previously reported extraction methods.

Results: The performance of the presented method demonstrated high accuracy and precision. A large range of HCQ concentrations was observed for the SLE patients in all three matrices (WB, serum, and plasma). The mean levels in WB were approximately two-fold the levels in serum and plasma $(813 \mathrm{ng} / \mathrm{mL}$ compared to $436 \mathrm{ng} / \mathrm{mL}$ and $362 \mathrm{ng} / \mathrm{mL}$, respectively). Spiked quality controls showed high reproducibility for all matrices (coefficient of variation, CV, approx. 5\%), whereas in patient samples, equally high-precision was only found using WB as the matrix (CV 3\%). The CV for serum and plasma was 14\% and 39\%, respectively. Two alternative methods applied to serum samples did not demonstrate improved precision.

Conclusions: A LC-HRMS method for the measurement of HCQ in human blood was developed and validated. Whole blood was found to be the superior sample matrix in terms of sample reproducibility. Thus, whole blood samples should be used for HCQ analysis when patients are monitored for HCQ treatment effects. The assay is in clinical use to monitor levels of HCQ in patients.

\footnotetext{
* Correspondence: Kim.Kultima@medsci.uu.se

${ }^{\dagger}$ Henrik Carlsson and Karin Hjorton contributed equally to this work.

'Department of Medical Sciences, Clinical Chemistry, Uppsala University,

Uppsala University Hospital, Entrance 61, 3rd floor, Dag Hammarskjölds Väg

18, SE-751 85 Uppsala, Sweden

Full list of author information is available at the end of the article
}

(c) The Author(s). 2020 Open Access This article is licensed under a Creative Commons Attribution 4.0 International License, which permits use, sharing, adaptation, distribution and reproduction in any medium or format, as long as you give appropriate credit to the original author(s) and the source, provide a link to the Creative Commons licence, and indicate if changes were made. The images or other third party material in this article are included in the article's Creative Commons licence, unless indicated otherwise in a credit line to the material. If material is not included in the article's Creative Commons licence and your intended use is not permitted by statutory regulation or exceeds the permitted use, you will need to obtain permission directly from the copyright holder. To view a copy of this licence, visit http://creativecommons.org/licenses/by/4.0/ The Creative Commons Public Domain Dedication waiver (http://creativecommons.org/publicdomain/zero/1.0/) applies to the data made available in this article, unless otherwise stated in a credit line to the data. 


\section{Introduction}

Systemic lupus erythematosus (SLE) is a chronic autoimmune disease affecting predominantly women, with an up to 9:1 ratio in the young and middle-aged [1]. The clinical phenotype varies from milder forms, typically with skin rash and arthritis, to severe, such as lupus nephritis or neuropsychiatric lupus, with a high risk of persistent organ damage, caused by either the inflammation or its treatment. Despite the variable clinical phenotype, antimalarials such as hydroxychloroquine (HCQ) and chloroquine phosphate are standard of care in SLE $[2,3]$, rheumatoid arthritis (RA) [4], or other inflammatory rheumatic diseases [5]. Recently, they have been suggested for treatment in COVID-19 patients [6]. Their benefits include improved survival, significant reduction of SLE flare risk as well as organ damage, delayed onset of disease, and less thrombotic events [7]. Hydroxychloroquine is more commonly used due to a more favorable side effect profile than chloroquine phosphate [8]. Studies have shown a correlation between low blood concentrations of HCQ and increased disease activity in SLE, as well as risk of flare $[9,10]$ and premature birth [11]. Drug concentrations vary considerably between individuals despite same dosing regimen and are influenced by factors like weight/BMI, glomerular filtration rate [12], non-adherence to therapy [13], and possibly genetic variations [14]. Furthermore, flares occur in some patients despite seemingly adequate treatment, the reasons for which, in many cases, are unclear. Since quinolones accumulate in pigmented tissue, a risk of permanent visual impairment due to eye deposits exists. As the risk increases with cumulative dose, approaching $10-20 \%$ after $16-20$ years $[15,16]$, the recommendations from the American Academy of Ophthalmology are a maximum dosage of $5 \mathrm{mg} / \mathrm{kg}$ real body weight and day $[17,18]$.

Determination of HCQ and its metabolites can be performed in whole blood (WB), serum, and plasma. Traditionally, HCQ levels have been determined in WB [19], whereas some recent studies have reported measuring HCQ in serum [20, 21]. One single study reported the levels in WB to be five times higher than those in plasma [22]. Direct comparisons of WB, serum, and plasma levels of HCQ in patients with SLE have not been reported.

The majority of HCQ measurements in human biofluids use liquid chromatography (LC) coupled to triple quadrupole $(\mathrm{QqQ})$ mass spectrometry (MS), where the analysis is performed in the multiple reaction monitoring mode [20, 23-26]. There are no methods presented using LC-high-resolution mass spectrometry (LCHRMS). LC-HRMS is advantageous since it allows the measurement of ions with high resolution and accuracy, enabling highly efficient filtering of ions for removal of interferences and background noise which may improve on detection and quantification limits.
The specific aims of the current study were to (i) establish and validate a method using LC-HRMS for the determination of blood HCQ concentration in HCQ/Plaquenil-treated SLE patients; (ii) determine the concentration of $\mathrm{HCQ}$ in WB, serum, and plasma and evaluate the reproducibility for the different matrices in matched samples; and (iii) perform a full validation of the LCHRMS method for the determination of HCQ concentrations, to be used in a clinical setting for TDM.

\section{Methods \\ Chemicals}

Acetonitrile (ACN, $\geq 99.9 \%$, MS grade, VWR Chemicals, Leuven, Belgium), formic acid (FA, ACS reagent grade), and ammonium formate (MS grade) from Merck (Darmstadt, Germany) and dimethyl sulfoxide (DMSO, HPLC grade) from Sigma-Aldrich (St. Louis, MO, USA) and water using Advantage A10 Milli-Q system (Merck Millipore, Burlington, MA, USA). Hydroxychloroquine sulfate $(1.0 \mathrm{mg} / \mathrm{ml}$ in methanol as free base) was obtained from LGC standards (Teddington, England) and hydroxychloroquine-d4 sulfate from Toronto Research Chemicals (North York, ON, Canada).

\section{Ethical approval}

All participants provided written informed consent, and the study was approved by the Regional Ethical Board of Uppsala (Dnr: 2019-02031).

\section{Samples}

Whole blood, serum, and plasma were jointly collected from 26 SLE patients at the Uppsala University Hospital. Pooled WB, serum, and plasma with no detectable HCQ were obtained from Uppsala University Hospital and used for blanks, calibrators, and quality controls. Whole blood was collected freshly from three additional SLE patients at the Uppsala University Hospital to evaluate the long-term stability of HCQ in WB. For the collection of WB and plasma, vacutainer tubes with EDTA as the anticoagulant were used, and for the collection of serum, tubes with no gel were used. The samples were stored at $-80^{\circ} \mathrm{C}$ until analysis.

\section{Patients}

All patients fulfilled $\geq 4$ of the classification criteria for SLE according to the 1982 American College of Rheumatology (ACR) or the 2012 Systemic Lupus International Collaborating Clinics (SLICC) [27, 28]. Patients were 49.5 years old (median) with a median disease duration of 10.5 years, and $81 \%$ were women (Table 1). All patients were administered HCQ in the form of $200 \mathrm{mg}$ Plaquenil $^{\circ}$ tablets. Out of the 26 patients, 14 were prescribed $1400 \mathrm{mg}$ (1 tablet daily), nine patients $2000 \mathrm{mg}$ (200 mg/day, 4 days; $400 \mathrm{mg} /$ day, 3 days per week), and two patients $2800 \mathrm{mg}$ Plaquenil weekly $(400 \mathrm{mg} /$ day). 
Furthermore, one patient had stopped taking Plaquenil but was included in the study as a control subject. A majority of patients (80\%) had low Systemic Lupus Erythematosus Disease Activity Index (SLEDAI 0-6) [29] at the time of blood sampling, 58\% were on at least one additional disease-modifying antirheumatic drug (DMARD), and the median prednisone dose was $1.25 \mathrm{mg}$ daily.

\section{Calibration curve and quality controls}

Calibration standards at seven levels ranging from 8.3$6075 \mathrm{ng} / \mathrm{mL}(8.3,25,75,225,675,2025,6075 \mathrm{ng} / \mathrm{mL})$ and quality control (QC) standards at three levels (lower limit of quantification (LLOQ) $8.3 \mathrm{ng} / \mathrm{mL}$; low (QCL) $25 \mathrm{ng} / \mathrm{mL}$; high $(\mathrm{QCH}) 4556.3 \mathrm{ng} / \mathrm{mL}$ ) were prepared in $95: 5 \mathrm{ACN}$ to DMSO (v/v). An internal standard (IS) solution of hydroxychloroquine-d4 (HCQ-d4) was prepared at a concentration of $80 \mathrm{ng} / \mathrm{mL}$ in $95: 5 \mathrm{ACN}$ to DMSO (v/v). These solutions were stored at $-20^{\circ} \mathrm{C}$. The LLOQ was defined as the lowest calibrator $(8.33 \mathrm{ng} / \mathrm{mL})$ following evaluation regarding accuracy and precision at this concentration level. Calibration standards and QC samples were prepared freshly for each analytical run. Weighted regression $\left(1 / x^{2}\right)$

Table 1 Characteristics of HCQ-treated SLE patients

\begin{tabular}{|c|c|}
\hline \multicolumn{2}{|l|}{ Patient characteristics $(\boldsymbol{n}=26)$} \\
\hline Females, $n(\%)$ & $21(81)$ \\
\hline Age years, median (range) & $49.5(20-79)$ \\
\hline Disease duration years, median (range) & $10.5(1-30)$ \\
\hline Number of ACR criteria, median (range) & $5(4-9)$ \\
\hline Number of SLICC criteria, median (range) & $7(4-12)$ \\
\hline SLICC/ACR damage index, median (range) & $0(0-4)$ \\
\hline SLEDAI at blood sampling, median (range) & $2(0-18)$ \\
\hline Creatinine ( $\mu \mathrm{mol} / \mathrm{L})$, median (range) & $70(41-178)$ \\
\hline Alanine aminotransferase ( $\mu \mathrm{kat} / \mathrm{L})$, median (range) & $0.43(0.16-0.87)$ \\
\hline $\mathrm{BMI}^{\mathrm{a}}$, median (range) & $25(18.4-35.3)$ \\
\hline HCQ dose 2800 mg/week, n (\%) & $2(8)$ \\
\hline HCQ dose 1800-2000 mg/week, n (\%) & $9(35)$ \\
\hline HCQ dose 1400 mg/week, n (\%) & $14(54)$ \\
\hline HCQ dose 0 mg/week, $n(\%)$ & $1(4)$ \\
\hline Prednisone dose, mg/day median (range) & $1.25(0-25)$ \\
\hline Azathioprine, $n(\%)$ & $7(29)$ \\
\hline Mycophenolate mofetil, $n$ (\%) & $2(8)$ \\
\hline Methotrexate, $n(\%)$ & $2(8)$ \\
\hline Intravenous immunoglobulins, $n$ (\%) & $2(8)$ \\
\hline Rituximab, n (\%) & $2(8)$ \\
\hline Belimumab, $n$ (\%) & $1(4)$ \\
\hline No other DMARDs, $n$ (\%) & $11(42)$ \\
\hline
\end{tabular}

${ }^{\mathrm{a}} \mathrm{BMI}$ available for 13 out of 26 patients

ACR American College of Rheumatology, SLICC Systemic Lupus International Collaborating Clinics [27, 28], SLEDAI Systemic Lupus Erythematosus Disease Activity Index [29], DMARD disease-modifying antirheumatic drug was used for the calibration curves using TraceFinder 4.1 from Thermo Scientific (Waltham, MA, USA).

\section{Sample preparation}

All samples were frozen at $-80^{\circ}$ for at least $24 \mathrm{~h}$ followed by thawing to ensure hemolysis of red blood cells. For each sample, $50 \mu \mathrm{L}$ (WB, serum, or plasma) was mixed with $20 \mu \mathrm{L}$ of IS. Proteins were precipitated by the addition of $130 \mu \mathrm{L}$ 95:5 ACN to DMSO, followed by vortexing and mixing for $5 \mathrm{~min}$ and centrifugation at $10000 \times \mathrm{g}$ for $10 \mathrm{~min}$. One hundred microliters of the supernatant was diluted with $900 \mu \mathrm{L} \mathrm{H}_{2} \mathrm{O}$. For calibrators and QC samples, $50 \mu \mathrm{L}$ of the blank sample was used and $50 \mu \mathrm{L}$ of either calibrator or QC working solution was added, followed by $20 \mu \mathrm{L}$ of IS and $80 \mu \mathrm{L}$ 95:5 ACN to DMSO prior to mixing and centrifugation as for the samples described above.

\section{Liquid chromatography-mass spectrometry analysis}

Fifty-microliter sample was injected on a reversed phase UPLC column (Accucore C18 $50 \times 2.1 \mathrm{~mm}, 2.6 \mu \mathrm{m}$, Thermo Scientific) using an Ultimate 3000 HPLC system (Thermo Scientific) interfaced to a high-resolution hybrid quadrupole Q Exactive Orbitrap MS (Thermo Scientific). A gradient was applied using the mobile phases $10 \mathrm{mM}$ ammonium formate and $0.4 \%$ FA in $\mathrm{H}_{2} \mathrm{O}$ (mobile phase A) and 0.4\% FA in ACN (mobile phase B): 5 $25 \%$ B for 2 min followed by washing at $95 \%$ B for $1 \mathrm{~min}$ and re-equilibration at $5 \% \mathrm{~B}$ for $1 \mathrm{~min}$, with a flow rate of $0.5 \mathrm{~mL} / \mathrm{min}(1.0 \mathrm{~mL} / \mathrm{min}$ during the washing step). The HRMS was operated in positive ionization mode with the following parameters: sheath gas flow rate 50, auxiliary gas flow rate 8 , sweep gas flow rate 3, spray voltage $4.5 \mathrm{kV}$, capillary temperature $320^{\circ} \mathrm{C}$, S-lens $\mathrm{RF}$ level 100 , and auxiliary gas heater $500^{\circ} \mathrm{C}$. The HRMS analysis was performed using targeted single ion monitoring, with the target $\mathrm{m} / z 338$ and an isolation window of $7 \mathrm{~m} / z$, collecting data in the profile mode with the resolution 70,000.

\section{Method validation}

The developed method was validated according to the guidelines for bioanalytical method validation defined by the European Medicines Agency (EMA;EMEA/CHMP/ EWP/192217/2009 Rev. 1.). The validation was performed using WB as the sample matrix.

The extent of carry-over was evaluated by injecting a series of blanks following the highest calibrator (6075 $\mathrm{ng} / \mathrm{mL}$ ) in each analytical run during the validation, comparing the HCQ peak area in these blanks with the peak area of the calibrator at the LLOQ level. Carry-over in the blank after a high concentration injection should not exceed $20 \%$ of the LLOQ.

Accuracy and precision were evaluated within-run and between-runs by analyzing five replicates of QC samples at 
the LLOQ, QCL, and QCH levels on four different days. The stability of prepared samples stored in the autosampler $\left(10^{\circ} \mathrm{C}\right)$ was evaluated by reinjection of five replicates of QCL and QCH samples after 48 and $72 \mathrm{~h}$. The stability of unprepared samples ( $4 \mathrm{~h}$ at RT) and for freezing (four cycles at $-80^{\circ} \mathrm{C}$ ) was evaluated using seven SLE patient samples.

The long-term stability of $\mathrm{HCQ}$ in WB (unprepared samples) in RT and refrigerator $\left(4^{\circ} \mathrm{C}\right)$ was evaluated over $168 \mathrm{~h}$ for freshly collected samples from three SLE patients. After aliquotation $(400 \mu \mathrm{L})$, samples were stored in RT or refrigerator and then frozen $\left(-80^{\circ} \mathrm{C}\right)$ at six different time points: $0 \mathrm{~h}, 8 \mathrm{~h}, 24 \mathrm{~h}, 48 \mathrm{~h}, 72 \mathrm{~h}$, and $168 \mathrm{~h}(1$ week). The samples were then thawed and prepared for analysis at one single occasion.

\section{Clinical application}

Whole blood, serum, and plasma from 26 SLE patients were analyzed using the described method. Four patients were sampled twice (two at an interval of 10 days and two at an interval of 60 days), thus amounting to a total of 30 samples analyzed for the three matrices. To evaluate the reproducibility in the three matrices, WB, serum, and plasma from eight patients were prepared and analyzed on a second occasion. Five replicates of QCL and QCH were prepared in each matrix both times.

\section{Statistical analysis}

The association between the measured HCQ levels in WB and weekly dose was modeled using linear mixed effect models [30], adjusting for age and gender. Hydroxychloroquine level was treated as dependent variable; patient, gender, and age as random effect variable; and weekly dose, as independent fixed effect variables. BMI was recorded for only 13 patients and therefore not included in the linear mixed effect model. The associations were evaluated using the likelihood ratio test. A $p$ value of $<0.05$ was considered statistically significant.

\section{Comparison with previously used protocols for extraction of HCQ from serum}

Two alternative methods for HCQ extraction from serum were selected to compare their reproducibility performance with the present method: an ACN-based method developed for serum [20] and a methanol-based method originally developed for WB [24]. In brief, the volume of solvent (ACN or methanol) was increased from 150 to
$200 \mu \mathrm{L}$ (sample-to-solvent ratio from 1:3 to 1:4) and following centrifugation mobile phase A was used to acidify and dilute the supernatants. Seven serum samples, as well as five QC samples at the QCL and QCH levels, were prepared with the three methods at two occasions. The reproducibility of the protocols was compared in terms of within- and between-run precision.

\section{Results}

\section{Method validation}

The developed method for LC-HRMS analysis of HCQ in WB displayed desirable robustness and selectivity. The assay exhibited linearity in the range $8.3-6075 \mathrm{ng} /$ $\mathrm{mL}$ with no interferences observed and with coefficients of determination $\left(R^{2}\right)>0.997$ for the calibration curves.

Following an injection of $6075 \mathrm{ng} / \mathrm{mL}$ HCQ (the highest calibrator), carry-over was observed at approximately $25 \%$ of the LLOQ $(8.3 \mathrm{ng} / \mathrm{mL})$. This was reduced to $5 \%$ by injecting two additional blanks (three blanks in total).

The within- and between-run accuracy and precision were within the recommended EMA guidelines, with bias $<15 \%$ in comparison with the nominal concentrations and $\mathrm{CV}<5 \%$ at each of the three evaluated levels (LLOQ $8.3 \mathrm{ng} / \mathrm{mL}$, QCL $25 \mathrm{ng} / \mathrm{mL}$, and QCH $4556.3 \mathrm{ng} / \mathrm{mL}$ ) (Table 2) in order to validate the accuracy and reproducibility of the measurements within the methodological range. The stability of the 48 and $72 \mathrm{~h}$ autosampler-stored QC samples $\left(10^{\circ} \mathrm{C}\right)$ agreed with the EMA guidelines (Table 2). The stability of unprepared samples at room temperature and after four repeated freeze-thaw cycles was satisfactory with an average $\mathrm{CV}<5 \%$ when comparing measured concentrations before and after storing treatment (Table 3).

The stability of HCQ in WB stored at RT or refrigerator $\left(4^{\circ} \mathrm{C}\right)$ was high with no significant difference in the measured HCQ concentration after up to $168 \mathrm{~h}$ (1 week) of storage at either temperature (Table 4). The average $\mathrm{CV}$ of the HCQ concentrations for the three patient samples measured at the six time points were $3.5 \%$ in $\mathrm{RT}$ and $3.2 \%$ in the refrigerator.

\section{Clinical applications}

The highest levels in patients were observed in WB, followed by serum and plasma (Table 2 and Fig. 1). In three patients, no HCQ was detected (one who had terminated HCQ (0 mg/week), and two prescribed $1400 \mathrm{mg} /$ week). A

Table 2 Intra- and inter-day precision (CV\%) and accuracy (bias\%) at three QC levels

\begin{tabular}{|c|c|c|c|c|c|c|c|}
\hline \multirow[b]{2}{*}{ QC level } & \multirow[b]{2}{*}{ Nominal concentration (ng/mL) } & \multicolumn{3}{|l|}{ Intra-day $(n=5)$} & \multicolumn{3}{|l|}{ Inter-day $(n=20)$} \\
\hline & & Mean concentration $\pm \mathrm{SD}(\mathrm{ng} / \mathrm{mL})$ & $\mathrm{CV} \%$ & Bias\% & Mean concentration $\pm \mathrm{SD}(\mathrm{ng} / \mathrm{mL})$ & CV\% & Bias\% \\
\hline LLOQ & 8.3 & $8.1 \pm 0.3$ & 3.2 & -3.3 & $7.8 \pm 0.4$ & 4.9 & -6.0 \\
\hline $\mathrm{QCL}$ & 25.0 & $23.3 \pm 0.3$ & 1.1 & -6.9 & $22.6 \pm 0.8$ & 3.5 & -9.5 \\
\hline $\mathrm{QCH}$ & 4556.3 & $4563.8 \pm 205.0$ & 4.5 & 0.2 & $4432.4 \pm 157.5$ & 3.6 & -2.7 \\
\hline
\end{tabular}


large range in HCQ concentrations was observed in all matrices. In patients with the 1400-mg weekly dosage and detectable HCQ $(n=12)$, the concentration range differed 7-fold (233-1606 ng/mL), 5-fold (159-868 ng/mL), and 8fold (153-1158 ng/mL) for WB, serum, and plasma, respectively. Patients with the 2000-mg HCQ/week dosage $(n=9)$ displayed a wider concentration range, differing 16fold (98-1522 ng/mL), 25-fold (41-1018 ng/mL), and up to 26-fold (23-611 ng/mL) for WB, serum, and plasma, respectively. The highest WB $(1989 \mathrm{ng} / \mathrm{mL})$ and serum (1194 $\mathrm{ng} / \mathrm{mL}$ ) levels were found in a patient prescribed $2800 \mathrm{mg} /$ week (Table 5 and Fig. 1). In the four patients sampled twice, the concentration range differed 1.1- to 2.3 -fold between the two occasions (Table 5).

The correlation between WB and serum was acceptable $\left(R^{2}=0.82\right)$, but comparisons involving plasma measurements showed unacceptably high variability $\left(R^{2}=\right.$ 0.46 for WB vs plasma and $R^{2}=0.52$ for serum vs plasma). The average relation between HCQ levels in the different matrices were for WB:serum:plasma 1:0.54: 0.44 . The accuracy and precision of QC samples at the $\mathrm{QCL}$ and $\mathrm{QCH}$ levels were high in all three matrices (CV and bias $<5 \%$ ).

The variation between the three matrices was unexpectedly high. To evaluate the reproducibility of the sample protocol, eight patient samples were extracted and analyzed at two separate occasions. A high reproducibility was observed for WB $\left(R^{2}=1.0, \mathrm{CV} 3 \%\right)$, whereas the reproducibility for serum was intermediate $\left(R^{2}=\right.$ $0.89, \mathrm{CV} 14 \%)$ and low for plasma $\left(R^{2}=0.72\right.$, CV $\left.39 \%\right)$. In contrast, the reproducibility of the QC sample was high (CV 3-5\%) in all matrices (Fig. 2 and Table 6).

\section{Comparison with other protocols for extraction of $\mathrm{HCQ}$ from serum}

In the repeated patient sample preparation and measurements, we found the CV to be high in serum and plasma compared to WB. In order to evaluate whether alternative extraction methods could improve the reproducibility observed for serum, the presented extraction protocol was modified to resemble that of Mok et al. [20] and Soichot et al. [24]. Seven patient serum samples were prepared using the three different protocols on two occasions. Although the QC sample reproducibility was consistently high across the three protocols (CV 2-4\%), none of the alternatives improved reproducibility in serum patient samples (CV 15-17\%) (Table 7).

Measurements of HCQ in WB were found to be superior to serum and plasma. The association between HCQ levels and weekly dose was modeled using the linear mixed effect model. There was a statistically significant $(p<0.05)$ association between HCQ levels in WB and weekly dose, but not in serum or plasma in this limited size study.

\section{Discussion}

Here, we present a fast and reproducible method for the determination of HCQ concentrations in blood from SLE patients using LC-HRMS. The method which is based on a total chromatographic time of four minutes shows good linearity in the range of 8.3 to 6075 $\mathrm{ng} / \mathrm{mL}$ and high reproducibility in spiked quality controls for plasma, serum, and WB matrices, respectively. In patient samples, however, high reproducibility could only be achieved measuring the HCQ concentration in WB. The reproducibility in serum was acceptable, yet in plasma unacceptably low. The superior reproducibility in WB is in line with a previous small pharmacokinetic study where plasma data were reported to be more variable than WB [22].

To further evaluate the reproducibility in patient samples, the current protocol was modified to resemble the protocols of Mok et al. [20] and Soichot et al. [24]. Reproducibility for QC samples was satisfactory for all three protocols. However, none of the methods showed any significant improvement with respect to serum patient samples (CV 15-17\%), compared to WB (3\%). Previous methods for HCQ analysis using LC-MS have been evaluated using QC samples, and the reproducibility of patient samples was not evaluated [20, 23-26]. Hydroxychloroquine is a drug with a plasma protein binding degree estimated to $50 \%$ [31], and it has been speculated that WB is favorable because of the technical challenges in separating blood cells and platelets from plasma [32].

These patients, who were on a stable dose of Plaquenil (>6 months), and thus expected to have reached equilibrium concentrations $[33,34]$, displayed HCQ levels in

Table 3 Short-term stability of samples. Stability of prepared samples stored in autosampler $\left(10^{\circ} \mathrm{C}\right)$, and stability of patient samples at RT and following repeated freeze-thawing

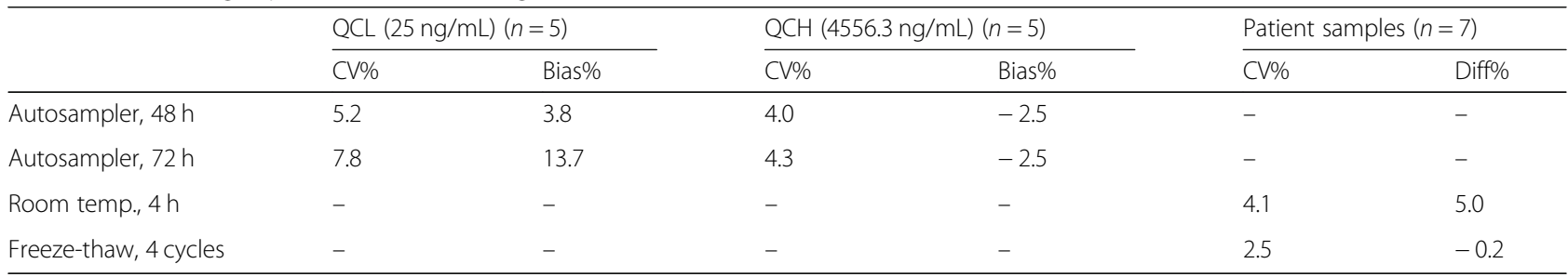

Bias\% percent difference from nominal conc., Diff\% average percent difference, measured conc. after storage subtracted from conc. prior 
Table 4 Long-term stability of HCQ in whole blood. HCQ concentrations in three WB samples stored up to $168 \mathrm{~h}(1$ week) at either in RT or in the refrigerator $\left(4^{\circ} \mathrm{C}\right)$

\begin{tabular}{|c|c|c|c|c|c|c|}
\hline \multirow[b]{2}{*}{ Hours } & \multicolumn{2}{|l|}{ Patient 1} & \multicolumn{2}{|l|}{ Patient 2} & \multicolumn{2}{|l|}{ Patient 3} \\
\hline & $\mathrm{RT}, \mathrm{ng} / \mathrm{mL}$ & Refrigerator, ng/mL & $\mathrm{RT}, \mathrm{ng} / \mathrm{mL}$ & Refrigerator, ng/mL & $\mathrm{RT}, \mathrm{ng} / \mathrm{mL}$ & Refrigerator, ng/mL \\
\hline 0 & 770 & & 432 & & 307 & \\
\hline 8 & 778 & 776 & 403 & 416 & 304 & 295 \\
\hline 24 & 777 & 755 & 421 & 411 & 293 & 307 \\
\hline 48 & 754 & 848 & 410 & 397 & 284 & 303 \\
\hline 72 & 784 & 760 & 429 & 391 & 325 & 295 \\
\hline 168 (1 week) & 756 & 780 & 449 & 410 & 291 & 305 \\
\hline Mean $\pm \mathrm{SD}(\mathrm{ng} / \mathrm{mL})$ & $770 \pm 13$ & $781 \pm 34$ & $424 \pm 17$ & $409 \pm 14$ & $301 \pm 15$ & $302 \pm 6$ \\
\hline CV\% & 1.6 & 4.3 & 3.9 & 3.5 & 4.9 & 1.9 \\
\hline
\end{tabular}

WB approximately twice the levels detected in both serum and plasma. This ratio is smaller compared to previous findings, reporting a WB-plasma ratio of approximately 5:1 [22]. Hydroxychloroquine concentrations vary considerably between individuals with the same dosing regimen. For example, in WB, there was up to 16-fold difference between individuals (2000 mg $\mathrm{HCQ} /$ week). This high inter-individual difference has also been reported by others $[9,12,32]$. There was also an up to 2.3-fold difference (in WB) between the occasions in patients that were sampled twice $(n=4)$, with no obvious connection to the time between sampling occasions (two at a 10-day interval and two at a 60-day interval). These observations point to the fact that HCQ concentrations cannot be predicted only based on the prescribed dose $[13,35]$.

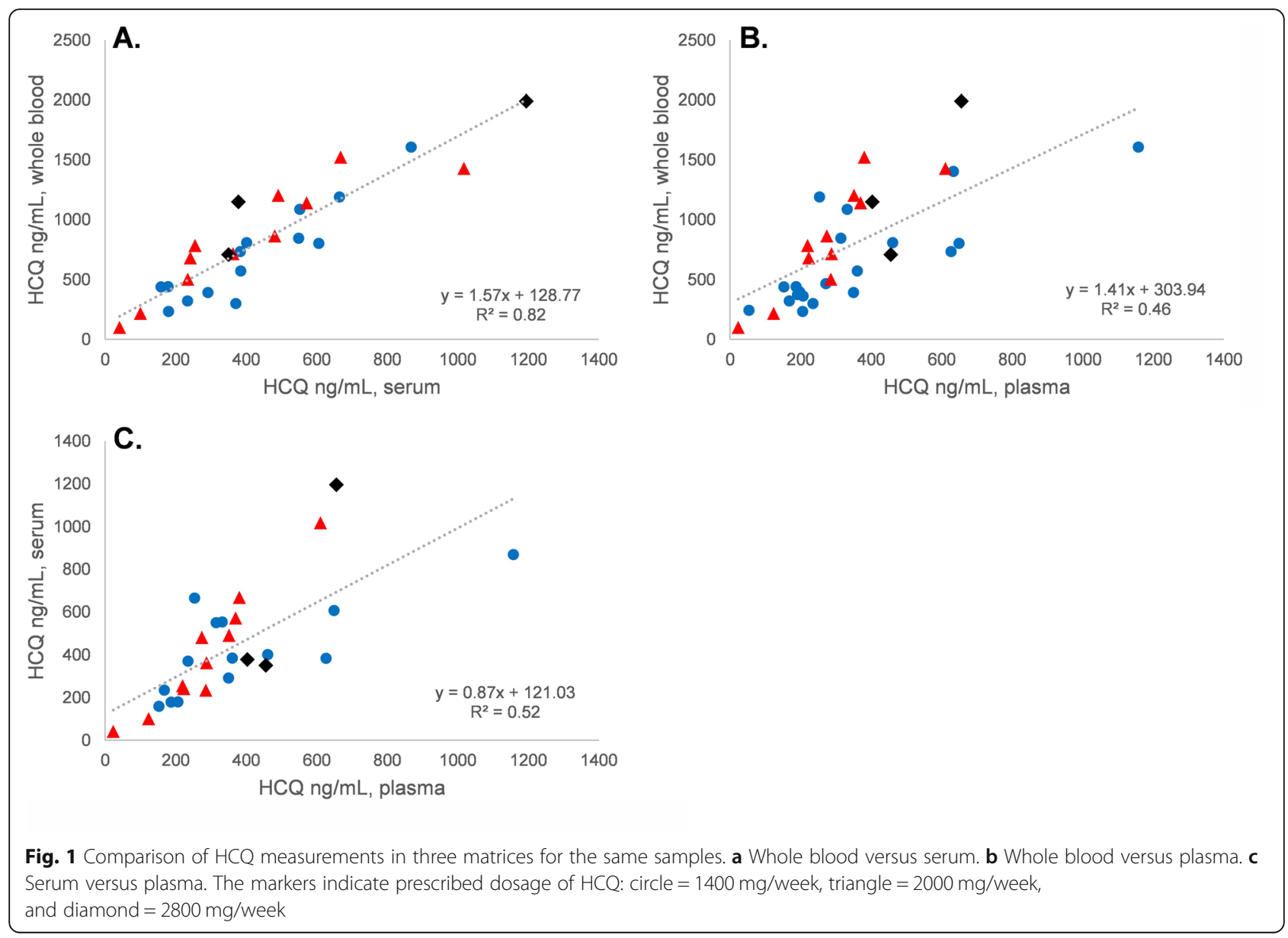


Table 5 Mean, standard deviation (SD), and range of HCQ $(\mathrm{ng} / \mathrm{mL})$ measured in the three matrices. Three dose levels were prescribed (1400, 2000, and $2800 \mathrm{mg} /$ week) and four patients (A-D) were sampled twice

\begin{tabular}{|c|c|c|c|}
\hline & \multicolumn{3}{|l|}{ HCQ Conc ng/mL } \\
\hline & Whole blood & Serum & Plasma \\
\hline Mean and range. All doses $\left(n=25^{\mathrm{a}}\right)$ & $813 \pm 466$ (n.d. $\left.^{\text {b }}-1989\right)$ & $436 \pm 270$ (n.d. $\left.{ }^{b}-1194\right)$ & $362 \pm 224$ (n.d. $\left.{ }^{b}-1158\right)$ \\
\hline Mean and range. Dose 1400 mg/week $(n=14)$ & $697 \pm 395$ (n.d.-1606) & $416 \pm 209$ (n.d.-868) & $390 \pm 271$ (n.d. -1158$)$ \\
\hline Mean and range. Dose 2000 mg/week $(n=9)$ & $832 \pm 461(98-1522)$ & $406 \pm 281(41-1018)$ & $287 \pm 152(23-611)$ \\
\hline Mean and range. Dose $2800 \mathrm{mg} /$ week $(n=2)$ & $1282 \pm 651(709-1989)$ & $641 \pm 480(350-1194)$ & $505 \pm 133(404-656)$ \\
\hline Patient A, 1st and 2nd sample, 10 days between samplings (2000 mg/week) & 503,216 & 235,100 & 286,124 \\
\hline Patient B, 1st and 2nd sample, 10 days between samplings ( 2000 mg/week) & 680,717 & 242,363 & 223,288 \\
\hline Patient C, 1st and 2nd sample, 60 days between samplings (1400 mg/week) & 390,298 & 292,371 & 350,235 \\
\hline Patient D, 1st and 2nd sample, 60 days between samplings ( 2800 mg/week) & 709,1147 & 350,378 & 456,404 \\
\hline
\end{tabular}

${ }^{a}$ The patient with no HCQ administered $(0 \mathrm{mg} /$ week) is excluded from this table

${ }^{\mathrm{b}}$ n.d. not detected; excluded from the calculation of mean and SD

The high stability of HCQ in WB, with no significant decrease in concentration after prolonged storage up to $168 \mathrm{~h}$, allows for collection of samples and transportation without the need of cooling or freezing. Importantly, however, samples need to be frozen at $-80^{\circ}$ for $24 \mathrm{~h}$ followed by thawing to ensure hemolysis of red blood cells. Shorter freezing period at $-80^{\circ}$ may be sufficient, but has not been evaluated in the current study.

In this very limited size study, intended for the evaluation of most suitable matrix for the determination of $\mathrm{HCQ}$, we found a significant association between the
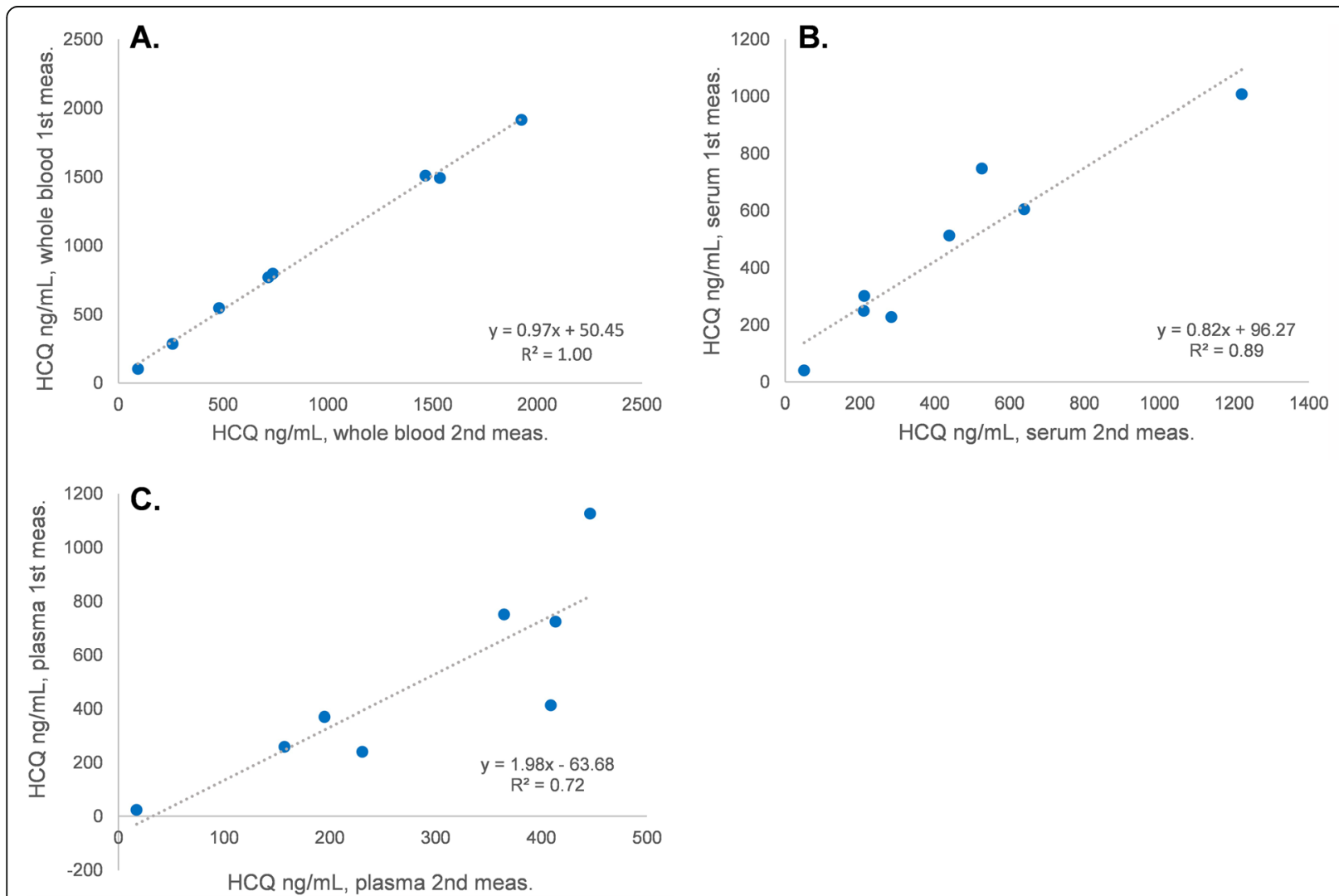

Fig. 2 Reproducibility testing. In order to evaluate the reproducibility of the method in the three matrices, eight patient samples were processed and analyzed on two occasions. $\mathbf{a}$, b, and $\mathbf{c}$ shows the results for whole blood, serum, and plasma, respectively. Reproducibility was high in WB, intermediate in serum, and low in plasma 
Table 6 Reproducibility testing. To evaluate the reproducibility of the protocol used, eight patient samples were extracted and analyzed at two separate occasions for all three matrices. Five QC samples (QCL and QCH) were prepared on both occasions. The reproducibility of the QC samples was high in all matrices and in patients' samples measuring WB

\begin{tabular}{llll}
\hline & Whole blood & Serum & Plasma \\
\hline Mean $(\mathrm{ng} / \mathrm{mL})^{\mathrm{a}}$ & 915 & 455 & 384 \\
SD $(\mathrm{ng} / \mathrm{mL})^{\mathrm{b}}$ & 27 & 65 & 148 \\
$\mathrm{CV}(\%)^{\mathrm{c}}$ & 3 & 14 & 39 \\
QCL $(25 \mathrm{ng} / \mathrm{mL}), \mathrm{CV} \%$ & 4 & 4 & 5 \\
QCH $(4556.3 \mathrm{ng} / \mathrm{mL}), \mathrm{CV} \%$ & 3 & 4 & 4 \\
\hline
\end{tabular}

${ }^{a}$ Mean of all measurements, eight samples measured twice

${ }^{b}$ Mean of the SD from comparing two measurements of the same sample, reflects reproducibility

'Mean of the CV from comparing two measurements of the same sample, reflects reproducibility

patient's weekly dose and HCQ levels in WB, in contrast to serum or plasma levels. Other factors including age, gender, and genetically determined drug metabolism may also influence patients' HCQ levels in blood [12, 14].

Hydroxychloroquine measurements in routine care can help clinicians motivate patients to improve treatment adherence, and to accordingly adjust doses, avoiding unnecessary addition of potentially more toxic therapy. Monitoring HCQ concentrations could also help minimize the risk of long-term side effects such as retinopathy, as recently demonstrated that HCQ blood levels predicted later hydroxychloroquine retinopathy [16]. The optimal concentration levels to balance these aims may require further evaluation [19].

\section{Conclusions}

The presented LC-HRMS method for the quantification of HCQ, validated using whole blood as the preferred sample matrix, was found to be superior to using serum and plasma. Hydroxychloroquine concentrations vary considerably between individuals with the same dosing regimen. The performance of the method meets the criteria defined by the EMA for method evaluation and is well suited for

Table 7 Evaluation of alternative protocols for HCQ levels in serum. Seven patient serum samples were prepared with the present method as well as the two alternative methods on two occasions. All methods showed high reproducibility for the measurement of HCQ in QC samples, but no method showed improved reproducibility for patient samples

\begin{tabular}{llll}
\hline Method & $\begin{array}{l}\text { Alt. Method } \\
1^{\mathrm{a}} \text { CV\% }\end{array}$ & $\begin{array}{l}\text { Alt. Method } \\
2^{\mathrm{b}} \text { CV\% }\end{array}$ & $\begin{array}{l}\text { Current method } \\
\text { CV\% }\end{array}$ \\
\hline Samples $(n=7)$ & 16 & 17 & 15 \\
QCL $(n=5)$ & 2 & 3 & 4 \\
QCH $(n=5)$ & 3 & 4 & 4
\end{tabular}

${ }^{\mathrm{a}}$ Based on the method by Mok et al. [20], using acetonitrile for precipitation

${ }^{b}$ Based on the method by Soichot et al. [24], using methanol for precipitation monitoring HCQ levels in SLE patients as well as other patient groups prescribed this drug. The assay is in use at the laboratory at the Uppsala University Hospital in Sweden to monitor levels of HCQ in patients. The laboratory is accredited by SWEDAC (SS-EN ISO 15189) to deliver results on patient samples for clinical care.

\section{Abbreviations \\ ACN: Acetonitrile; DMSO: Dimethyl sulfoxide; EMA: European Medicines Agency; FA: Formic acid; HCQ: Hydroxychloroquine; HRMS: High-resolution mass spectrometry; LC: Liquid chromatography; LLOQ: Lower limit of quantification; MeOH: Methanol; MS: Mass spectrometry; SLE: Systemic lupus erythematosus; TDM: Therapeutic drug monitoring; QC: Quality control; QCL: Quality control with low concentration; QCH: Quality control with high concentration; WB: Whole blood}

\section{Acknowledgements}

This work was supported by Region Uppsala (ALF-grant and R\&D funds), the Swedish Rheumatism Association, King Gustaf V's 80-years Foundation, and the Swedish Society of Medicine (the Ingegerd Johansson donation).

\section{Authors' contributions}

HC, SA, and KK developed the analytical method, analyzed the samples and data, and wrote the manuscript. $\mathrm{KH}$ was responsible for collecting the samples and contact with patients, designed the study, and wrote the manuscript. LR, TÅ, and KK conceptualized and designed the study and wrote the manuscript. The authors read and approved the final manuscript.

\section{Funding}

This work was supported by Region Uppsala (ALF-grant and R\&D funds), the Swedish Rheumatism Association, King Gustaf V's 80-years Foundation, and the Swedish Society of Medicine (the Ingegerd Johansson donation). Open access funding provided by Uppsala University.

\section{Availability of data and materials}

The datasets used and/or analyzed during the current study are available from the corresponding author on reasonable request.

Ethics approval and consent to participate

All participants provided written informed consent, and the study was approved by the Regional Ethical Board of Uppsala (Dnr: 2019-02031).

\section{Consent for publication}

All authors read and approved the final manuscript.

\section{Competing interests}

All authors declare no competing interests.

\section{Author details}

'Department of Medical Sciences, Clinical Chemistry, Uppsala University, Uppsala University Hospital, Entrance 61, 3rd floor, Dag Hammarskjölds Väg 18, SE-751 85 Uppsala, Sweden. ${ }^{2}$ Department of Medical Sciences, Rheumatology, Uppsala University, Uppsala, Sweden.

Received: 29 January 2020 Accepted: 1 May 2020

Published online: 01 June 2020

References

1. Pons-Estel GJ, Alarcón GS, Scofield L, Reinlib L, Cooper GS. Understanding the epidemiology and progression of systemic lupus erythematosus. Semin Arthritis Rheumatism. 2010:257-68. https://doi.org/10.1016/j.semarthrit.2008. 10.007.

2. Bengtsson AA, Rönnblom L. Systemic lupus erythematosus: still a challenge for physicians. J Intern Med. 2017:52-64. https://doi.org/10.1111/joim.12529.

3. Shippey EA, Wagler VD, Collamer AN. Hydroxychloroquine: an old drug with new relevance. Cleve Clin J Med. 2018:85:459-67.

4. Smolen JS, Landewé R, Breedveld FC, Buch M, Burmester G, Dougados M, et al. EULAR recommendations for the management of rheumatoid arthritis with synthetic and biological disease-modifying antirheumatic drugs: 2013 
update. Ann Rheumatic Dise. 2014:492-509. https://doi.org/10.1136/ annrheumdis-2013-204573.

5. Schrezenmeier E, Dörner T. Mechanisms of action of hydroxychloroquine and chloroquine: implications for rheumatology. Nat Rev Rheumatol. 2020; 16:155-66.

6. Gautret P, Lagier J-C, Parola P, Hoang VT, Meddeb L, Mailhe M, et al. Hydroxychloroquine and azithromycin as a treatment of COVID-19: results of an open-label non-randomized clinical trial. Int J Antimicrob Agents. 2020:105949. https://doi.org/10.1016/j.ijantimicag.2020.105949.

7. Petri M, Purvey S, Fang H, Magder LS. Predictors of organ damage in systemic lupus erythematosus: the Hopkins Lupus Cohort. Arthritis Rheumatism. 2012:4021-8. https://doi.org/10.1002/art.34672.

8. Ruiz-Irastorza G, Ramos-Casals M, Brito-Zeron P, Khamashta MA. Clinical efficacy and side effects of antimalarials in systemic lupus erythematosus: a systematic review. Ann Rheum Dis. 2010;69:20-8.

9. Costedoat-Chalumeau N, Amoura Z, Hulot J-S, Hammoud HA, Aymard G, Cacoub P, et al. Low blood concentration of hydroxychloroquine is a marker for and predictor of disease exacerbations in patients with systemic lupus erythematosus. Arthritis Rheumatism. 2006:3284-90. https://doi.org/10. 1002/art.22156.

10. Durcan L, Clarke WA, Magder LS, Petri M. Hydroxychloroquine blood levels in systemic lupus erythematosus: clarifying dosing controversies and improving adherence. J Rheumatol. 2015;42:2092-7.

11. Balevic SJ, Cohen-Wolkowiez M, Eudy AM, Green TP, Schanberg LE, Clowse MEB. Hydroxychloroquine levels throughout pregnancies complicated by rheumatic disease: implications for maternal and neonatal outcomes. J Rheumatol. 2019:57-63. https://doi.org/10.3899/jrheum.180158.

12. Jallouli M, Galicier L, Zahr N, Aumaitre O, Francès C, Le Guern V, et al. Determinants of hydroxychloroquine blood concentration variations in systemic lupus erythematosus. Arthritis Rheumatol. 2015:2176-84. https:// doi.org/10.1002/art.39194.

13. Costedoat-Chalumeau N, Amoura Z, Hulot J-S, Aymard G, Leroux G, Marra $D$, et al. Very low blood hydroxychloroquine concentration as an objective marker of poor adherence to treatment of systemic lupus erythematosus. Ann Rheum Dis. 2007;66:821-4.

14. Lee JY, Vinayagamoorthy N, Han K, Kwok SK, Ju JH, Park KS, et al. Association of polymorphisms of cytochrome P450 2D6 with blood hydroxychloroquine levels in patients with systemic lupus erythematosus. Arthritis Rheumatol. 2016;68:184-90.

15. Melles RB, Marmor MF. The risk of toxic retinopathy in patients on longterm hydroxychloroquine therapy. JAMA Ophthalmol. 2014;132:1453-60.

16. Petri M, Elkhalifa M, Li J, Magder LS, Goldman DW. Hydroxychloroquine blood levels predict hydroxychloroquine retinopathy. Arthritis Rheumatol. 2019. https://doi.org/10.1002/art.41121.

17. Marmor MF, Kellner U, Lai TYY, Melles RB, Mieler WF. Recommendations on screening for chloroquine and hydroxychloroquine retinopathy (2016 revision). Ophthalmology. 2016:1386-94. https://doi.org/10.1016/j.ophtha. 2016.01.058.

18. Abdulaziz N, Shah AR, McCune WJ. Hydroxychloroquine. Curr Opin Rheumatol. 2018:249-55. https://doi.org/10.1097/bor.0000000000000500.

19. Costedoat-Chalumeau N, Galicier L, Aumaître O, Francès C, Le Guern V, Lioté $F$, et al. Hydroxychloroquine in systemic lupus erythematosus: results of a French multicentre controlled trial (PLUS Study). Ann Rheum Dis. 2013: 1786-92. https://doi.org/10.1136/annrheumdis-2012-202322.

20. Mok CC, Penn HJ, Chan KL, Tse SM, Langman $\sqcup$, Jannetto PJ. Hydroxychloroquine serum concentrations and flares of systemic lupus erythematosus: a longitudinal cohort analysis. Arthritis Care Res. 2016;68: 1295-302.

21. Balevic SJ, Green TP, Clowse MEB, Eudy AM, Schanberg LE, CohenWolkowiez M. Pharmacokinetics of hydroxychloroquine in pregnancies with rheumatic diseases. Clin Pharmacokinetics. 2019:525-33. https://doi.org/10. 1007/s40262-018-0712-z.

22. Tett SE, Cutler DJ, Day RO, Brown KF. A dose-ranging study of the pharmacokinetics of hydroxy-chloroquine following intravenous administration to healthy volunteers. Br J Clin Pharmacol. 1988;26:303-13.

23. Füzéry AK, Breaud AR, Emezienna N, Schools S, Clarke WA. A rapid and reliable method for the quantitation of hydroxychloroquine in serum using turbulent flow liquid chromatography-tandem mass spectrometry. Clin Chim Acta. 2013;421:79-84.

24. Soichot M, Mégarbane B, Houzé P. Chevillard L, Fonsart J, Baud FJ, et al. Development, validation and clinical application of a LC-MS/MS method for the simultaneous quantification of hydroxychloroquine and its active metabolites in human whole blood. J Pharm Biomed Anal. 2014:131-7. https://doi.org/10.1016/j.jpba.2014.07.009.

25. Fan H-W, Ma Z-X, Chen J, Yang X-Y, Cheng J-L, Li Y-B. Pharmacokinetics and bioequivalence study of hydroxychloroquine sulfate tablets in Chinese healthy volunteers by LC-MS/MS. Rheumatol Ther. 2015;2:183-95.

26. Wang $L-Z$, Ong RY-L, Chin T-M, Thuya W-L, Wan S-C, Wong AL-A, et al. Method development and validation for rapid quantification of hydroxychloroquine in human blood using liquid chromatography-tandem mass spectrometry. J Pharm Biomed Anal. 2012;61:86-92.

27. Tan EM, Cohen AS, Fries JF, Masi AT, Mcshane DJ, Rothfield NF, et al. The 1982 revised criteria for the classification of systemic lupus erythematosus. Arthritis Rheumatism. 1982:1271-7. https://doi.org/10.1002/art.1780251101.

28. Petri M, Orbai A-M, Alarcón GS, Gordon C, Merrill JT, Fortin PR, et al. Derivation and validation of the Systemic Lupus International Collaborating Clinics classification criteria for systemic lupus erythematosus. Arthritis Rheum. 2012;64:2677-86.

29. Gladman DD, Ibañez D, Urowitz MB. Systemic lupus erythematosus disease activity index 2000. J Rheumatol. 2002;29:288-91.

30. Bates $D$, Mächler M, Bolker B, Walker S. Fitting linear mixed-effects models using Ime4. J Stat Softw. 2015. https://doi.org/10.18637/jss.v067.i01.

31. McLachlan AJ, Cutler DJ, Tett SE. Plasma protein binding of the enantiomers of hydroxychloroquine and metabolites. Eur J Clin Pharmacol. 1993;44:481-4.

32. Munster T, Gibbs JP, Shen D, Baethge BA, Botstein GR, Caldwell J, et al. Hydroxychloroquine concentration-response relationships in patients with rheumatoid arthritis. Arthritis Rheum. 2002:46:1460-9.

33. Wallace DJ. Antimalarial agents and lupus. Rheum Dis Clin N Am. 1994;20: 243-63.

34. Tett SE, Cutler DJ, Day RO, Brown KF. Bioavailability of hydroxychloroquine tablets in healthy volunteers. Br J Clin Pharmacol. 1989;27:771-9.

35. Feldman CH, Collins J, Zhang Z, Subramanian SV, Solomon DH, Kawachi I, et al. Dynamic patterns and predictors of hydroxychloroquine nonadherence among Medicaid beneficiaries with systemic lupus erythematosus. Semin Arthritis Rheum. 2018:48:205-13.

\section{Publisher's Note}

Springer Nature remains neutral with regard to jurisdictional claims in published maps and institutional affiliations.

Ready to submit your research? Choose BMC and benefit from

- fast, convenient online submission

- thorough peer review by experienced researchers in your field

- rapid publication on acceptance

- support for research data, including large and complex data types

- gold Open Access which fosters wider collaboration and increased citations

- maximum visibility for your research: over $100 \mathrm{M}$ website views per year

At BMC, research is always in progress.

Learn more biomedcentral.com/submissions 